\title{
Reklamlarda Erkeklik: GQ ve Men's Health Dergilerindeki Reklamların Eleştirel Bir Okuması
}

\section{Masculinity in Advertising: A Critical Reading of Advertisements in GQ and Men's Health Magazines}

\author{
Özgür Kılınç, Anadolu Üniversitesi, Türkiye, ozgurkilinc@anadolu.edu.tr
}

\begin{abstract}
Öz: Reklamlar tarafindan yaratılan anlam dünyası temsiller, metaforlar ve söylemler üzerinden inşa edilmekte ve reklamin alıcısina sunulmaktadır. Bir kültür içerisinde biçimlenerek alıcıya sunulan reklamlar, temsile yönelik çeşitli analizler yapmayı mümkün kılmaktadır. Reklamlarda temsil edilen kodlardan biri de erkekliktir. Çalışmada erkekliğin temsili, reklamda görülen içeriğin ardında yer alan ekonomik, siyasal ve kültürel anlamların eleştirel bir yorumundan, bu anlamların nasıl inșa edildiğinden ve toplumsal olan ile ilişsisinden hareketle GQ ve Men's Health dergilerinde yer alan altı reklam üzerinden incelenmiştir. Reklamların sadece ikisinde çok kisa bir metin yer aldiğından ve dört reklamda ise marka ismi dışında herhangi bir metin olmadığından analiz daha çok bakıș, duruș, dokunma ve erkeklik tipi gibi görsel öğelerin eleștirel bir yorumu temel alınarak yapılmaya çalıșllmıștır. Anahtar Kelimeler: Erkeklik, Temsil, Söylem, Eleştirel Görsel Analiz
\end{abstract}

Abstract: The world of meaning which is created by advertisements builds on representations, metaphors and discourse, and then is presented to receiver of the ads. The ads that are formed within a culture enable various cultural analyses. Masculinity is one of the codes that are represented in advertising. In this study, the representation of masculinity is critically analysed, with reference to economical, political and cultural meanings that exist behind the visible content. This study also references, how these meanings are built and their relationship to the social. Six advertisements from GQ and Men's Health magazines were reviewed. Two of the ads had a very short text apart from the brand names, and the remaining ads were text-free, therefore analyses were based on a critical approach towards visual elements such as gaze, posture, touching and types of masculinity.

Keywords: Masculinity, Representation, Discourse, Critical Visual Analysis

\section{Giriş}

Bir toplumdaki baskın ekonomik, siyasal ve kültürel kodların yansıma alanlarından biri olan reklamlar, topluma ve kültüre dair birçok farklı okuma yapmayı mümkün kılan metinlerdir. Dolayısıyla reklamların işlev ve amaçları toplumsal bir form içerisinde şekillenip yine aynı form içerisinde reklamın alıcısında bir anlam dünyası yaratmaktadır. Diğer bir deyişle reklamlar tarafindan yaratılan anlam dünyası temsiller, metaforlar ve söylemler üzerinden inşa edilmekte ve reklamın alıcısına sunulmaktadır. Söz konusu anlamlar ise alıcılar tarafından farklı biçimlerde yorumlanmaktadır.

Reklamlarda farklı biçimlerde inşa edilip sunulan kodlardan biri de “erkeklik”tir. Erkekliğin en eski biçimi ciddi, gergin, kaslı ve aile sorumluluğunu reddeden bir söylem üzerine kuruluyken 19.yy’da Sanayi Devrimi ile birlikte yoğun emek gerektiren işlerde bedene duyulan ihtiyacın azalmasıyla erkeklik de bir krize girmiştir. Erkeksi ve kuvvetli imajı sürdürme ihtiyacı 1800'lerin sonu ile 1920'lere kadar güçlü erkek çağııı ortaya çıkarmıştır. 1920'lerin ortalarından 1940'ların başlangıcına kadar tipik erkek beyaz bir kadın partneri olan şeklinde tanımlanmıştır. 1940 ve 50'lerde ise erkeklik, erkeğin sadece eğlenme amacını taşıdığı playboy erkeklik şekline dönüşmüştür. Bir diğer dönüşüm ise 1960'ların ortalarında çiçek çocuklarla yaşanmıştır. 1990'lar ise rahatına düşkün, içsel gücünü koruyabildiği ölçüde erkeksi olan yeni erkeğin çıkışını temsil etmektedir (Bassett, 2009: 8).

Hall'e göre (1997: 3-15) bir kültürün üyeleri arasında anlamın üretildiği ve değiştirildiği bir sürecin temel bir parçası olan temsil, şeyleri temsil eden dilin, işaretlerin ve imgelerin kullanımını içermektedir. Şeylere anlamlarını, onları nasıl temsil ettiğimizle, onlar hakkında kullandı̆̆ımız kelimelerle, anlattığımız hikayelerle, ürettiğimiz imgelerle, onlarla ilişkilendirdiğimiz duygularla, onları sınıflandırma ve kavramsallaştırma biçimlerimizle ve onlara yüklediğimiz değerlerle veririz.

Reklamlarda erkekliğin nasıl temsil edildiğine odaklanan bu çalışmanın amacı daha çok erkek okuyuculara yönelik olan GQ ve Men's Health dergilerinde yer alan altı reklamdaki erkeklik temsilini incelemektir. Reklamlar analiz edilirken temel alınan beş erkeklik tiplemesi şunlardır: Tüketici ve erotik (Rohlinger, 2002: 66), trendi ve androjen (Shaw ve Tan, 2014: 121) ve melankolik erkek (Lemish ve Lahav, 2004: 149). Çalışmada, incelenen reklamlarda metin çok az yer aldığından Wang'ın (2014: 282) söylemi de bir kategori olarak içeren "eleştirel görsel analiz" kavramsallaştırmasından yararlanılmıştır. Bu bağlamda söz konusu reklamlar bakış, duruş, dokunma, erkeklik tipi gibi çeşitli kodlardan hareketle analiz edilmiştir. Başka bir deyişle söylem, reklamda yer alan bakış, duruş, dokunma ve erkeklik tipi tarafindan inşa edilen, dolaşıma sokulan ve işleyen bir şey olarak değerlendirilmiş (Canpolat, 2005: 106) reklamlar yorumlanırken konu ile ilgili çeşitli çalışmalara da atıfta bulunulmuştur. 


\section{Erkeklik ve Reklamlarda Erkekliğin Temsili}

Erkeklik, erkek olmanın toplumsal olarak kabul biçimi olarak tanımlanabilir. Erkeklik birçok farklı erkeklik biçimlerinden oluşmakta ve yine birçok farklı biçimde ifade edilmektedir. Bir kişinin kendi erkeklik kavramsallaştırması, tarihsel bağlam, sınıf, etnisite, kültür, yaş, evlilik durumu, cinsellik gibi çeşitli faktörlere bağlıdır. Dolayısıyla erkeklik sabit bir inşa olmayıp farklı biçimlerde inşa edilen bir kavramdır. Erkeklik üzerine yapılan araştırmalar erkekliği, "temsil olarak erkeklik", "deneyim olarak erkeklik" ve "harekete geçiren erkeklik" olmak üzere üç biçimde kavramsallaştırmıştır (Tuncay, 2005: 106). Üç̧ kavramsallaştırma biçiminin toplumsal, kültürel ve politik olarak inşa edildiği söylenebilir.

Ricciardelli vd.'nin (2010: 65) erkeklik sınıflandırmasının temsil, deneyim ve canlandırmayı (performans) kapsadığı düşünülebilir. Ricciardelli vd. erkeklik biçimlerini genel olarak kaslı, metroseksüel ve delikanlı olmak üzere üçe ayırmıştır. Kaslı beden imgeleri erkek bedeninin nasıl olması gerektiğini, kolay ulaşılamayan ideal bir bedeni sunmaktadır. Geleneksel erkeklikten bir kopuşu ifade eden ve 1970'lerde ortaya çımaya başlayan metroseksüellik ise 80’lerde erkeklere yönelik bakım ürünlerinin ve modanın gelişmesiyle daha da yaygınlık kazanmaya başlamıştır. Gençlik, hazcı tüketim, bekarlık ve kadınların nesneleştirilmesi ile cinsiyetçilik üzerinden inşa edilen, metroseksüellik ve feminizme karşı çıkan delikanlı erkeklik ise 1990’larda ortaya çıkmıştır.

Erkeklik yazınında karşımıza çıkan kavramlardan biri de hegemonik erkekliktir. Connell'e göre (1998: 245) kadınlık ve erkeklik biçimlerinin karşılıklı ilişkisi, erkeklerin kadınlar üzerindeki küresel egemenliği gibi tek bir yapısal gerçek üzerine oturtulur. Bu yapısal olgu, bir bütün olarak toplumda hegemonik bir erkeklik biçimini tanımlayan erkeklerarası ilişkilerin ana temelini oluşturur. Hegemonik erkeklik daima kadınlarla ilgili olduğu kadar, ikincil konuma itilmiş çeşitli erkeklik biçimleriyle ilgili olarak da inşa edilmektedir.

Erkekliğin inşa edildiği, üretildiği ve yeniden üretildiği alanlardan biri de reklamlardır. Neden kaslı vücut ideal vücut olarak algılanmakta ya da zaman içerisinde ne değişti de reklamlarda ideal kadın vücudunun yanı sıra ideal bir erkek vücudu da sunulmaya başlandı?

Son otuz yıldır, cinsiyetin reklamlarda temsili üzerine iletişim, pazarlama, psikoloji, sosyoloji ve toplumsal cinsiyet çalışmalarında çok sayıda araştırma yapılmıştır. Cinsiyetin, pazarlama faaliyetlerinde temel değişkenlerden biri olması pazarlama araştırmacılarını bu konuyu araştırmaya yöneltmiştir. Yine reklamların izleyici, dinleyici ya da okuyucuların toplumsal gerçekliğe yönelik algıları, reklamlardaki cinsiyet temelli stereotipleştirmenin toplumsal ve psikolojik etkileri çeşitli araştırmalara konu olmuştur (An ve Kim, 2007: 181-182).

1950’lerden beri Batı medyasında erkek bedeninin ticari temsiline yönelik özellikle filmler ve televizyon reklamları ile basılı reklamlarda belirgin bir artış meydana gelmişsir. Reklamlardaki erkek karakterler ideal erkeklik imgesini temsil etmektedir. Dolayısıyla reklamcılar da ürünlerini satışa yönelik bir araç olarak erkek karakterlerin temsil ettiği ideal erkeklik imgeleri ile ilişkilendirmektedir (Shaw ve Tan, 2014: 118). Söz konusu imgeler de kendi içerisinde sınıflandırılmıştır. Örneğin Rohlinger (2002: 66-67) reklamlarda yer alan erkek karakterleri dokuz kategoriye ayırmıştır. Söz konusu kategoriler şu şekildedir:

$\checkmark \quad$ Kahraman: Reklamda spor, ticaret ya da siyaset alanından ünlü birinin kullanılmasıdır.

$\checkmark \quad$ Doğa Erkeği: Doğa ya da hayvanlar üzerinde kontrol sağlamaya çalışan erkektir.

$\checkmark \quad$ Aile Babası: Erkeğin, çocuklarıla veya aile üyeleriyle faal bir şekilde bir etkinliğe katılımını temsil

etmektedir.

$\checkmark \quad$ Evin Direği: Ailesel etkinliklere katılmayan fakat çocuklarını veya ailesini yöneten erkektir.

$\checkmark \quad$ Çalışan Erkek: Erkeğin bir işin uzmanı veya profesyoneli olduğu şeklinde yansıtılmasıdır.

$\checkmark \quad$ Tüketici Erkek: Reklamda erkek karakter ile ürün arasında doğrudan bir ilişkinin olması, karakterin ürünü kullanmasidır.

$\checkmark \quad$ Kentli Erkek: Şehirlerin yaşam tarzından ve modadan zevk alan, barlar ve sosyal aktivitelerden hoşlanan erkek tasviridir.

$\checkmark \quad$ Sakin Erkek: Erkeğin, sakin bir hayata sahip olduğu şeklinde temsil edilmesidir.

$\checkmark \quad$ Erotik Erkek: Erkeğin bedeninin yalnız veya başkalarıyla beraber sergilenmesidir. Reklamda cinsellik iması ve fiziksellik vurgusu vardır.

Yukarıda sıralanan erkeklik temsillerinin aynı zamanda birer imge oldukları ve reklamların da imgeler üzerinden inşa edildiği bilinmektedir. Bordo (2000'den aktaran Alexander, 2003: 539) imgelerin aktif olduğunu dile getirmekte, ona göre, en inandırıcı imgeler öznellikle yayılmakta başka bir deyişle bu imgeler bizimle konuşmakta ve bizi tahrik etmektedir. Bu imgeler diğer nesneler gibi (sandalye, masa) onları istediğimiz gibi kullanmamıza izin vermemektedir. Daha doğrusu söz konusu imgeler ruhumuz, arzularımız ve kendilik algımız üzerinde oldukça fazla bir güce sahiptir. Çeşitli imgelerin yer aldığı sembolik bir temsil ve sunum alanı olan reklamlar ideolojik çözümleme için oldukça elverişlidir (Lull, 2001: 24). Yoğun bir anlam ve söylem deposu olan reklamlardaki imgelerin çeşitli yan anlamlar yarattıkları düşünülebilir. Bu imgelerden biri olan beden de tüketim kültürü tarafindan farklı yan anlamlarla biçimlendirilip sunulmaktadır.

Bordo (2000'den aktaran Alexander, 2003: 539) özellikle popüler kültürde erkek bedenlerinin bizimle konuşma yollarını incelemiştir. Ona göre reklamlarda erkek bedenlerinin iki mesajı bulunmaktadır. İlki erkeklikle yüz yüze gelmek; 
ikincisi ise yaslanmaktır. Erkeklikle yüz yüze gelmek, erkek karakterin reklamın alıcısına soğuk bir şekilde gözünü dikmesi, kendisini güçlü, zırhlı, duygusal olarak anlaşılamaz şeklinde sunarak meydan okumasıdır. Yaslanmak ise bir şeye karşı yaslanan veya bir şeye dayanan bir bedeni tanımlamakta ve kadın imgelerinde de yaygın olarak kullanılmaktadır. Yaslanma durumu pasif olmayıp reklamın alıcısını bedenin yanında aktif bir biçimde oyalanması için davet eder. Bordo'ya göre her iki mesaj biçiminin işlevi tüketicilere ürünü satmak ve geç yirminci yüzyıl tüketimciliğinin girdabını sürekli genişletmektir.

\section{Eleştirel Görsel Analiz}

Eleştirel görsel analiz, söylem, metin ve görsel metaforların incelenmesine dayanmaktadır (Wang, 2014: 282). Kress ve Van Leeuwen’a göre (1996'dan aktaran Pritchard, 2001: 82) görsel iletişimin analizi hem bir sistemi hem de görsel iletişimi kapsayan eleştirel disiplinler açısından önemlidir. Göstergebilim ve söylem yaklaşımını içeren yöntemler, "görsel yapıların anlamı nasıl kavradığını" -tıpkı dilsel yapıların yaptığı gibi- ortaya koyması bakımından daha eleştirel bir kavramsal çerçeve sunmaktadır. Öte yandan göstergebilimsel yaklaşım metnin mekaniğini ve şiirselliğini anlamayı mümkün kılarken söylemsel yaklaşımlar ise temsilin etkilerini ve sonuçlarını diğer bir deyişle politikasını anlamayı mümkün kılmaktadır. Bu çalışmada da reklamlar, göstergebilimsel yaklaşım yerine söylem, metin ve görselliğin eleştirel bir okumasıyla yorumlanmaya çalışılmıştır. Eleştirel görsel analizin söylem boyutu ise eleştirel söylem analizi ile ilişkilidir. Eleştirel söylem analizi genel olarak değerlendirilmeden önce Şekil 1'de eleştirel görsel analizi oluşturan kategorilere değinilmektedir.

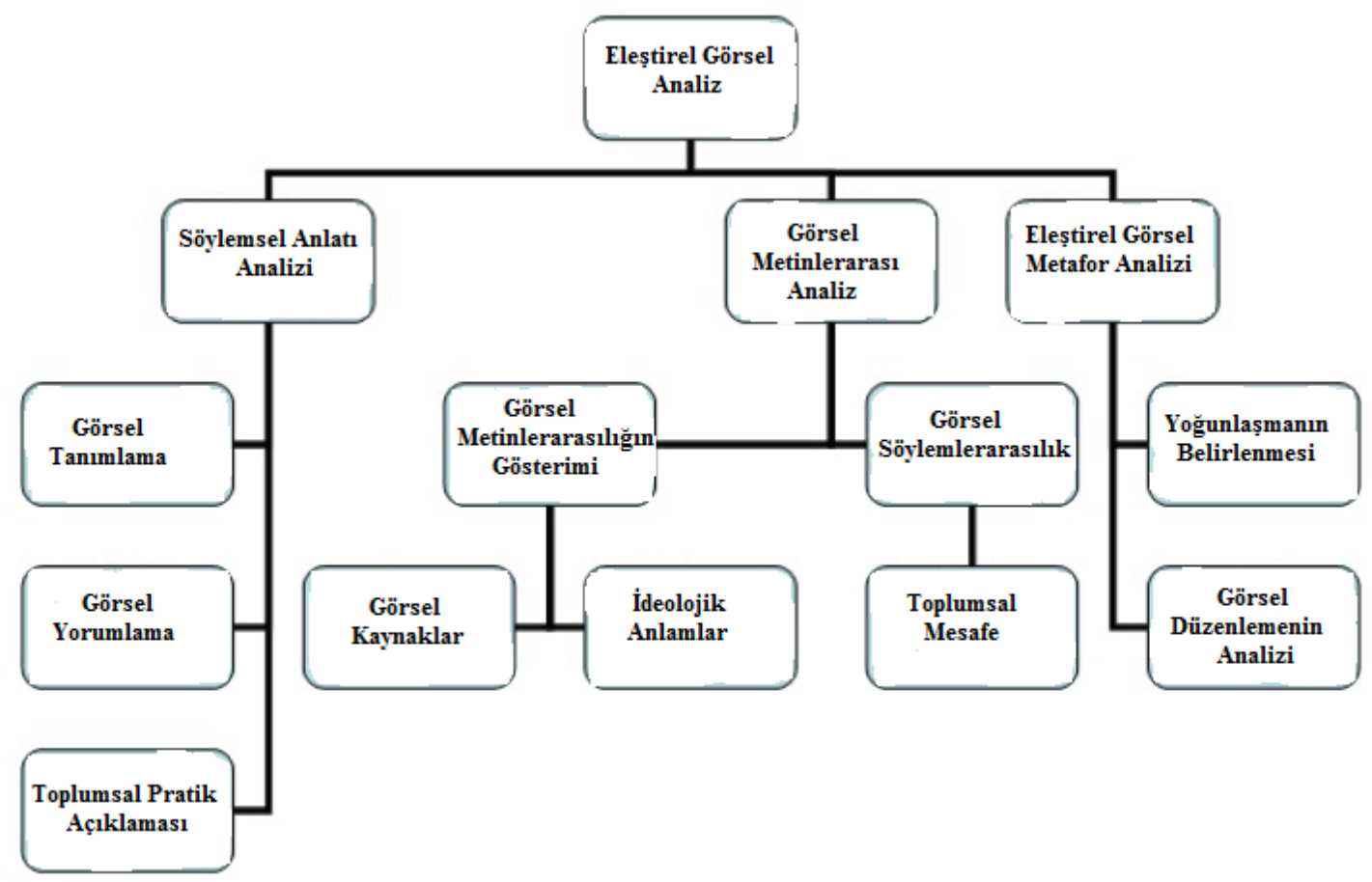

Şekil 1. Eleştirel Görsel Analizin Kavramsallaştırılması

Kaynak: Wang, 2014: 282

Şekil 1'e göre eleştirel görsel analizin genel olarak söylem, metin ve görsel metaforlardan oluştuğu görülmektedir.

Eleştirel söylem analizi, toplumsal güç istismarının, egemenliğin ve eşitsizliğin metne ve konuşmanın kendisine dayanılarak nasıl düzenlendiğini toplumsal ve politik bir bağlamda incelemektedir. Eleştirel yaklaşımlar söylemin, gücü, ideolojiyi, toplumsal kimlikleri, bilgi sistemleri ve inancı nasıl şekillendirdiğini ve onlar tarafından nasıl şekillendirildiğini ortaya çıkarmayı amaçlamaktadır (van Dijk, 2003: 352; Fairclough, 1992: 9). Fairclough ve Wodak (1997’den aktaran van Dijk, 2003: 353) eleştirel söylem analizinin temel ilkelerini şu şekilde sıralamaktadır:

$\checkmark \quad$ Eleştirel söylem analizi toplumsal sorunlara işaret eder.

$\checkmark \quad$ Güç ilişkileri söylemseldir.

$\checkmark \quad$ Söylem, toplumu ve kültürü oluşturur.

$\checkmark \quad$ Söylemin ideolojik işlevi vardır.

$\checkmark \quad$ Söylem tarihseldir.

$\checkmark \quad$ Metin ve toplum arasındaki ilişki aracılanmıştır.

$\checkmark \quad$ Söylem analizi yorumlayıcı ve açıklayıcıdır. 
$\checkmark \quad$ Söylem, toplumsal eylemin bir şeklidir.

Çalışmada, incelenen reklam örneklerinin sadece ikisinde kısa bir metin yer almakta diğerlerinde ise marka adları dışında herhangi bir metin bulunmamaktadır. Dolayısıyla reklamlar, daha çok görsellikten yola çıkılarak değerlendirilmiştir. Bu bağlamda söylem, metin ve görsel metaforları içeren eleştirel görsel analiz kavramsallaştırmasından hareketle konu ile ilgili çeşitli çalışmalar temel alınarak altı reklam incelenmeye çalışılmıştır.

İncelenen reklamlar daha çok erkek okuyuculara yönelik olan GQ ve Men's Health dergilerinden seçilmiştir. Reklamlar seçilirken farklı erkeklik kategorilerini temsil etmelerine ve reklamda kadın karakterlerin yer almasına dikkat edilmiştir. Seçilen reklamlar, söylemin yanı sıra şu görsel öğeler üzerinden değerlendirilmiştir: Bakış, duruş, dokunma ve erkeklik tipi.

\section{4. Örnek Reklam Analizleri}

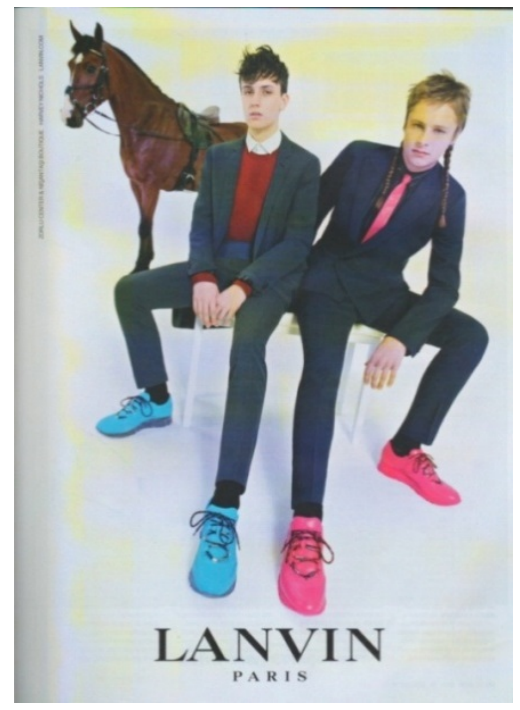

Resim 1

Kaynak: GQ, Ekim 2014: 45.

Goldman'a göre (1992'den aktaran Khoo ve Karan, 2007: 34) reklamcılığı ideolojik bir alan olarak görmemekteyiz. Oysa ekonomik, toplumsal kurumların bir parçası olan ve meta ilişkilerinin egemenliğini sürdürmeye yarayan tüketim kültürünü benimsemek için toplumdaki bireyler reklamlar aracılı̆̆ıyla etkilenilmeye çalışılmaktadır. Günümüzde bireyler arası etkileşim genellikle maddi varlık ve metalar tarafından tanımlanmaktadır. Resim 1'deki reklamda, oturan iki erkek doğrudan reklamın alıcısına/okuyucusuna bakmaktadır. Reklamlarda eril bakış genelde alıcıya/okuyucuya doğru olurken; dişil bakış ise başka bir nesneye ya da kadının kendisine doğru yönelmektedir. Yine kadın çoğu zaman bir bakışın nesnesi, aracı iken; erkek, bakışın öznesi konumundadır. Dolayısıyla erkek, reklamda bakış aracılığıyla kendi varlığını daha bir hissedilir kılmaktadır. Shaw ve Tan'ın (2014: 132) reklamlardaki erkeklik sınıflandırmasından hareketle bu reklamda yer alan erkek karakterlerin trendi erkek kategorisinde oldukları söylenebilir. Söz konusu erkeklik biçimi, reklamlarda son moda giysiler ile soğuk bir bakış üzerinden alıcı/okuyucuyla erkek karakter arasına mesafe konularak inşa edilmektedir. Her iki erkek karakter birbirine temas etmektedir.

Katz (2003) medyanın tıpkı kadınlara yaptığı gibi erkeklere yönelik de "gerçek erkek" olma tanımı yaptığını belirtmektedir. Dolayısıyla erkeklik çoğu zaman fiziksel dayanıklılık, kontrol ve saldırgan güç üzerinden tanımlanmakta, şiddet içeren bir erkeklik rolü etkileyici sporcular, süper kahramanlar ve ünlüler tarafından temsil edilmektedir. Oysa bu reklamdaki erkek karakterler hegemonik erkeklik alanının dışında kodlanmışlardır. Çünkü örgülü saçlara sahip, renkli kravat, kazak ve ayakkabılar giyen iki erkek karakterin egemen toplumsal cinsiyet kodlarını yapısökümüne uğrattıkları düşünülebilir. Fakat göz önünde bulundurulması gereken önemli göstergelerden biri de söz konusu yapısökümünün yine tüketim kültürü kodları içerisinde gerçekleşmesidir. Öyle ki bu kültür, bedende, yaşam tarzında ve hayatın birçok alanında bir özgürleşme yanılgısı üzerine kuruludur. Featherstone'nun (2013: 155) deyimiyle tüketim kültürü içerisinde modern bireyin sadece elbiseleriyle değil, bir beğeniden yoksun olup olmadığını gösterecek şekilde, evi, mobilyaları, dekorasyonu, otomobili ve diğer faaliyetleriyle de konuştuğunun bilincine varması sağlanır. 
Bu reklamda atın kullanılması da dikkat çekmektedir. Hall'e göre (1997: 3-15) şeylerin kendi başına nadiren sabit, tek ve değişmeyen anlamları vardır. İnsanlara, nesnelere ve olaylara anlamlarını veren bir kültürün katılımcılarıdır. Temsil ise anlam ve dili kültür ile birleştirmektedir. Dolayısıyla bu reklamda at hangi anlamı temsil etmektedir? Reklamlarda hayvanların kullanımı bir anlam aktarımını sağlamaktadır. At çoğu kez güç, hız, kovboyluk ve savaş gibi egemen erkeklik kodlarını temsil etmektedir. Örneğin, Marlboro'nun meşhur "Marlboro Man" imgesi atlı kovboy mitine dayanmaktadır. Son olarak belirtilmesi gereken bu reklamdaki erkek karakterlerin hegemonik erkeklik dışında konumlandırılmaları ile erkeksi bir anlatı biçimi olarak atın kullanılması tezat bir durumdur. Başka bir okumayla erkekliğin aynı anda çok farklı, akışkan, zıt formlarının mevcut olduğu söylenebilir.

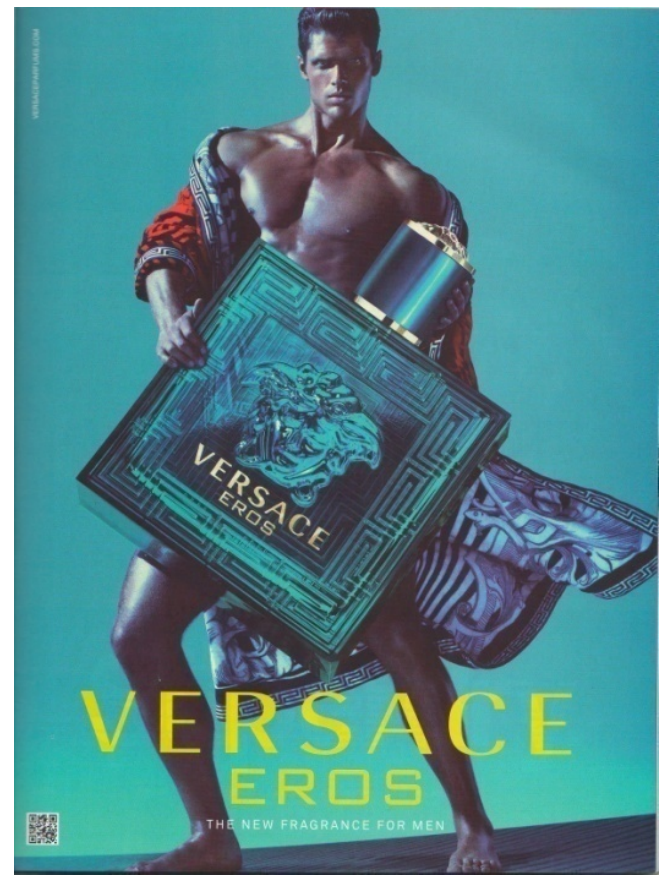

Resim 2

Kaynak: Men's Health, Kasım 2014: 19.

Resim 2'de bir parfüm reklamı yer almaktadır. Otantik giysili, yarı çıplak ve kaslı bir erkek ile sergilenen parfüm şişesi erkeğin yarı çıplak vücudunun bir kısmını kapatmaktadır. Erkeğin bakışı alıcıya/okuyucuya doğrudur. Erkek karakterin vücudunun bu reklamda parfümü benzerlerinden farklılaştırmak için bir imge olarak kullanıldığı görülmektedir. Williamson’a göre (2001: 24) parfümler hiçbir özel anlamlılığa sahip olamadıklarından, bunlar imge yaratmanın en iyi örneğini verirler. $\mathrm{Bu}$, ürün hakkında hiçbir gerçek bilgi veremeyen (bir koku hakkında ne bilgi verilebilir ki?) bir reklam türüdür; öyle ki ürünü, benzer diğer ürünlerden farklılaştırma işlevi, bütünüyle reklam dünyasının dışından alınan bir imgeyle bağlantı kurmaya dayanır. 
Postmodern toplumda erkeğin cinsel kimliği ile erkekliğin popüler kültürdeki imgeleri arasında tamamlayıcı bir ilişki vardır. Kültürel birer ürün olarak imgeler, erkeklerin değişen erkeklik anlayışlarını yansıtmaktadır. Popüler kültür ile inşa edilen erkekliğin bu yeni formu tüketici merkezli bir ekonomide markalanmış erkeklik kavramını ortaya çıkarmıştır.

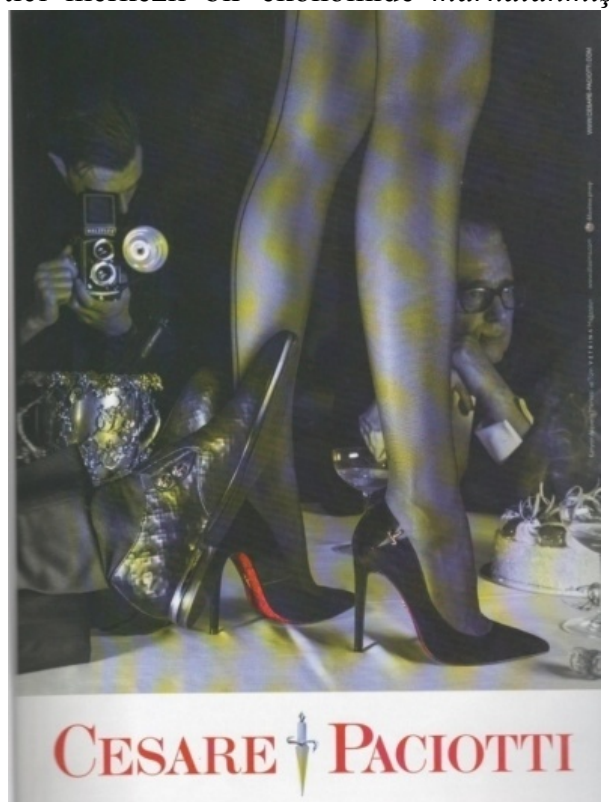

Erkeklere yönelik moda, bakım ürünleri, yaşam tarzı dergileri yapısal bir değişimin olduğunu göstermektedir. Diğer bir deyişle erkeklik artık aynı zamanda erkeğin ne tükettiği üzerinden tanımlanmaktadır (Alexander, 2003: 551). Erkeğin ne tükettiği ile kurulan erkeklik kendi içerisinde bir anlatıya sahiptir. Bu reklamda erkek tarafindan parfüm şişesinin tutulması bir anlatı olarak değerlendirilebilir. Bu anlatının, kısmen dikey olarak tutulan parfüm şişesi ile fallus merkezli bir anlam yaratılması üzerinden kurulduğu düşünülmektedir. Yine bu reklamda erkeklere yönelik bir bakım ürünü olan parfümün geleneksel erkeklik ile metroseksüellik arasındaki diyalektiği yarattığı ve erkeklik kimliğinin inşası ya da yeniden inşasında bu diyalektiğin önemli bir rol oynağı söylenebilir (Harrison, 2008: 63-70). Parfüm şişesi aracıllğıyla yaratılan markalanmış erkekliğin bu reklamdaki temsilinin erotik fakat daha baskın olarak karakterin üzerindeki giysiden kaynaklı androjen olduğu öne sürülebilir.

\section{Resim 3}

Kaynak: GQ, Ekim 2014: 63

Resim 3'te bir ayakkabı markasının reklamı yer almaktadır. Reklamda masa etrafında oturan iki erkeğin yüzü görülürken, masanın üzerinde bir kadın bacağı ve ona dokunan bir erkek ayağı da görülmektedir. Yüzü görünen erkeklerden biri masa veya ürün yerine (ayakkabı) bakışını başka bir yere odaklamışken diğer erkek ise ürünün fotoğrafını çekmektedir. Dokunmanın, reklamda odak noktası olduğu görülmektedir. Bu dokunmanın, erkek bedeniyle özdeşleştirilen fiziksel güç ve denetim üzerinden kurgulandığı düşünülebilir. Trujillo (1991'den aktaran Crane, 2003: 233) çağdaş erkekliğin temsil biçimi olarak dört pratikten bahsetmektedir. Bunlar; erkek bedeniyle özdeşleştirilen fiziksel güç ve denetim, erkeklerle toplumsal, kadınlarla cinsel ilişki kurma,"erkek mesleği" sayılan işlerdeki mesleki başarı ve ataerkil aile rolüdür.

Erkek bedeniyle özdeşleştirilen fiziksel güç ve denetimin yanı sıra erkeklerle toplumsal, kadınlarla cinsel ilişki kurmanın yukarıdaki reklamda somutlaştığı görülmektedir. İdeal seyirci her zaman erkek olarak kabul edildiğinden bu reklamda erkekler gözetleyen/bakan, kadın ise gözetlenen/bakılan konumundadır (Berger, 2014: 64). Gözetleyen erkeğin de içerisinde yer aldığı hegemonik erkeklik, diğer erkeklik biçimlerinden özellikle bağımlı erkeklikten ayrılmaktadır. Erkekliğin bu biçimi olması gereken erkeklik olarak görülmenin yanı sıra diğer erkeklerin de kendilerini bu kavramla konumlandırmalarını istemekte ve ideolojik olarak kadınları baskı altına almayı meşrulaştırmaktadır (Connell ve Messerschmidt, 2005: 832).

$\mathrm{Bu}$ reklamda üzerinde durulması gereken bir diğer nokta ise ürün ile cinsiyet arasındaki ilişkidir. Kadının gösteri nesnesi olması, erkeğin sadece ayağıyla temsil edilen bir özne olması bazı ürünlerin kültürel, ekonomik ve toplumsal olarak cinsiyet etrafında kodlandığını göstermektedir. Bu reklam özelinde, kültürel boyutun cinsiyetin anlamlandırma ve temsiline, ekonomik boyutun cinsiyet ve üretimin ilişkisine, toplumsal boyutun ise cinsiyeti alımlamaya denk geldiği öne sürülebilir. Son olarak, reklamda, yoğun bir cinsellik iması ve fiziksellik vurgusu olduğundan kadına dokunan erkeğin erotik erkek kategorisinde olduğu düşünülebilir. 


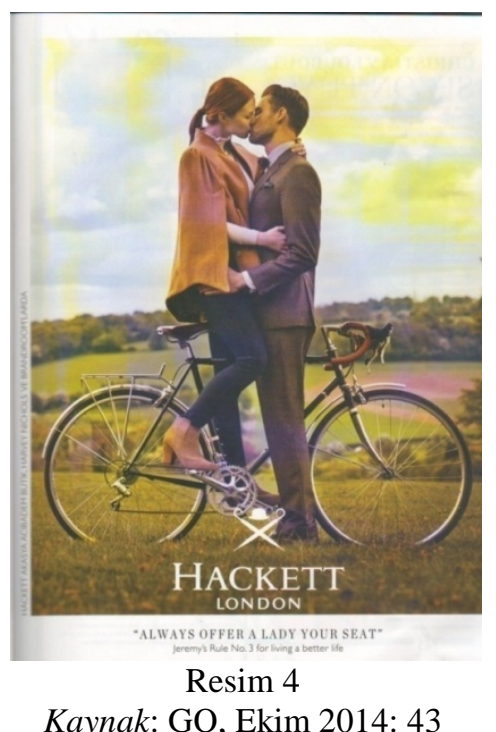

Coltrane ve Adams (1997: 334-335) reklamlarda cinselliğin genel olarak üç şekilde kullanıldığını öne sürmektedir. İlki, kadının ya da erkeğin başka bir cinsel bakışın ya da kendi bakışının (aynada kendine bakmak gibi) nesnesi olması; ikincisi cazibeli bir davranışın bulunması (flört etme, göz kırpma gibi); üçüncüsü ise etkileyici kıyafetlerin kullanılmasıdır (kıyafetin olmaması da dahil olmak üzere). Sadece erkeklere yönelik bir giysi markası reklamının yer aldığı Resim 4'te hem erkek hem de kadının bütün vücudu görülmektedir. Erkek karakter ayakta dururken, kadın karakter ise bisikletin üzerinde, erkek karakterden biraz daha baskın olarak ayakta durmaktadır. Her iki karakterin gözleri kapalı olduğundan bakış ne okuyucuya, ne birbirlerine ne de başka bir nesne ya da özneye yönelmiştir. Bakışın "arzu” ya yöneldiği dolayısıyla reklamdaki cinselliğin hem arzu hem de karşıllıklı dokunma üzerinden inşa edildiği söylenebilir. Erkekliğin şekillendirilen bir kavram olduğunu belirten Slevin ve Linneman'a göre (2009: 1) erkeklerin, erkekliğin ne olduğunu anlamalarında ve bunu pratiğe dökmelerinde beden önemli bir rol oynamaktadır. Yine tek bir erkeklik biçimi yerine yaş, sınıf, etnisite ve cinsellik üzerinden şekillendirilen farklı/çoklu erkeklik biçimleri bulunmaktadır. Reklamdaki erkek ile ürün arasında doğrudan bir ilişki olduğundan erkek karakter tüketici erkek olarak tanımlanabilir. Tüketici erkekliğin kendini inşa ettiği söylem alanları ise kentli, eğitimli ve iyi bir gelir seviyesine sahip olmaktır.

Giyim tercihleri, insanların kendi yaşamlarını kavrama yollarından biri olduğundan, erkeklerin giysi seçimleri de toplumsal konumlarını nasıl yorumladıklarını gösterir (Crane: 2003: 260). Reklamda sadece erkeklere yönelik giysi üreten bir marka ismi görülmektedir. Marka isminin altında ise şu metin yer almaktadır:

"Daha iyi bir yaşam için Jeremy'nin 3 numaralı kuralı: Bir kadına her zaman oturduğun yeri teklif et."

Purvis ve Hunt’a göre (2014: 21-22) erkeklerin kadınlar için kap1 açmaları ve kadınlar odaya girdiklerinde ayağa kalkmaları, düzenleyici çerçevesini kadınların hem ikincil bir konumda oldukları hem de erkekler tarafından itina gösterilmeye ve korunmaya ihtiyaç duydukları keskin bir cinsel iş bölümünün oluşturduğu bir söylemin bileşenleridir. Yukarıdaki düzenleyici bir söylem içeren metinde genel olarak mekan algısının erkeklik üzerinden kurulduğu söylenebilir. $\mathrm{Bu}$ reklamda mekanın doğa, aracın ise bisiklet olduğu görülmektedir. Doğa çoğu zaman kadınlık ile özdeşleştirilirken araç ise erkeklik ile özdeşleştirilir. Mekandaki araç, yan anlamıyla "bisikletin üzerinde olması gereken erkek iken, bu erkek yerini bir kadına vermiştir" şeklinde okunabilir. Yine Plumwood (2004: 13) "doğa" olarak tanımlanmak demek, edilgen olarak, fail olmayan veya özne olmayan olarak, aklın ve kültürün kazanımlarının (bu kazanımlar da genelde beyaz, Batıll, erkek uzman veya girişimcinin eseri sayılır) yer aldığı "ön plan"ın "çevre"si ya da görünmez "arka plan" koşulları olarak tanımlanmak demektir, şeklinde doğanın erkek egemen bir söylemin tahakkümü altında olduğunu vurgulamaktadır. 


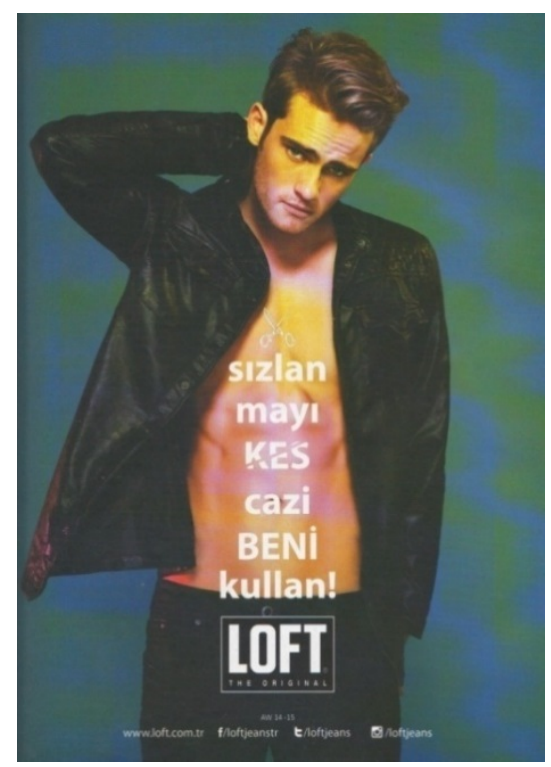

Resim 5

Kaynak: GQ, Ekim 2014: 99.

Baudrillard (2013: 149) bedenin bir tüketim nesnesi olduğunu şu şekilde belirtmiştir: Tüketilen şeyler arasında diğer nesnelerden daha güzel, daha kıymetli, daha eşsiz, otomobilden bile daha fazla yan anlamla yüklü bir nesne vardır. Bu nesne bedendir. Bir giysi markasına ait reklamda erkek bir karakter tek başına gösterilmektedir. Doğrudan alıcıya/okuyucuya doğru bakmakta olan karakterin kaslı vücudunun bir kısmı görünmekte ve görünen kısım yarı çıplak bir şekilde sunulmaktadır. Kaslı vücut aynı zamanda güç olarak somutlaşmaktadır. Fakat bu gücün kaynağı toplumsal olarak inşasında yatmaktadır. Nasıl ki kadın karakterlerin yer aldığı reklamlarda ideal bir beden algısı temsil ediliyorsa bu reklamda da ideal bir erkek bedeni algısı gösterilmektedir. Yine ideal beden, güç ve cinsellikle özdeşleşen erkek karakter kendisine dokunmaktadır. Reklamdaki karakteri en iyi şekilde erotik erkek ifadesi tanımlamaktadır.

Kimliğin, kültürel ve bireysel kavranışını etkileyen reklamlardaki temsiller, toplumsal ve kültürel pratiklerdeki değişimlerin bir sonucu olarak okunmalıdırlar (Schroeder ve Zwick, 2004: 24). Tüketim kültürü ve reklamların eleştirel bir analizi, temsile dair çeşitli kodları açmayı sağlamaktadır. Örneğin, beyaz olan ve ideal bir beden algısını içeren Barbie bebeğin piyasaya çıkmasından bir süre sonra yine beyaz ve ideal bir bedene denk gelen Ken ortaya çıkmıştır. Narsistik tüketim kültürü bir yandan kendi ideallerini üretirken diğer yandan bu idealleri reklamlar aracillğıyla sunmaktadır. Dolayısıyla erkek bedeninin toplumsal inşası ve sunumu hasta olanı, şekilsiz olanı, ideale uymayanı dışlama pratikleriyle birlikte şekillenmiş ve reklamlarda Barbie ve Ken'in insan halleri yer almaya başlamıştır. Bu reklamdaki egemen söylemin "sızlanmayı bırak, kaslı erkekliğini kullan" olduğu düşünülebilir. Dil, anlam üzerinde yapılacak oyun ve müdahalelere açıktır, çünkü sözcükler insanlar için şeylerdir. Bu şeyleşme dilsel oyunlar için bir alan yaratır (Çoban, 2005: 280). Sızlanma, dilin gündelik hayattaki cinsiyetçi kullanımında ve toplumsal algılarda genellikle kadınlığa atfedilen bir kavramdır. Yine reklamda kullanılan ve emir bildiren bir ifade olan kes! otoriteryen bir dilin varlığını göstermektedir. Kes! ifadesi görsel olarak makas ile ilişkilendirilip yarı çıplaklığa geçişe de kapı aralamıştır. 


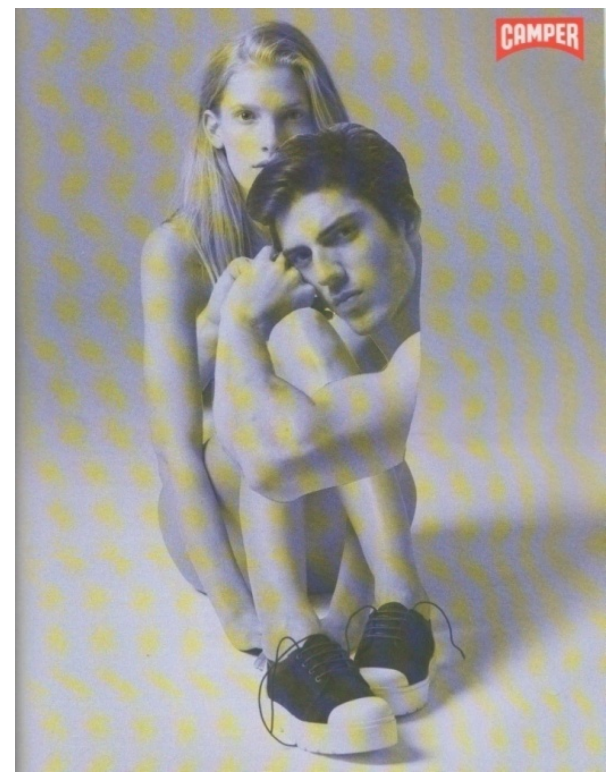

Resim 6

Kaynak: GQ, Ekim 2014: 167

Bir ayakkabı firmasına ait Resim 6'daki reklamda bir kadın ve bir erkek karakter yer almaktadır. Kadın karakterin vücudunun belli bir kısmı görülürken, erkek karakterin sadece kafası ve kolu görülmektedir. Kadının çıplak bedeninin bir kısmı hem kendisi hem de erkek tarafından kapatılmaktadır. Erkeğin kaslı kolu kadının bacaklarına temas etmektedir. Her iki karakter de doğrudan alıcıya/okuyucuya bakmaktadır.

Anlam değişimi sürecini kodlama ve kodaçımlama yapıları üzerinden tartışan Hall'ün (1993'den aktaran Chan ve Leung, 2005: 125-126) kavramsallaştırmasından hareketle reklam söylemlerinde tamamen düz anlamdan ya da doğal temsilden bahsedilemez. Dolayısıyla reklamlardaki her görsel işaret bir durumu, değeri ya da anlamı ifade etmektedir. Bu reklamda, ürünü sergileyen kadın olup erkek ile ürün arasında doğrudan bir ilişki yoktur. Tüketici ideolojisi kadın üzerinden inşa edilirken, duruş biçimi olarak kadın, erkekten daha yüksekte görünse de erkek özellikle bakış ve dokunma anlamında daha merkezi bir konumda bulunmaktadır.

Çoklu erkeklik kimliğinin yansıdığı alanlardan biri ve kültürel bir form olan reklamlarda son yirmi yıl içerisinde tanıdık olmayan iki erkeklik biçimi daha ortaya çıkmıştır. İlki, duygularını ifade eden duygusal erkek, ikincisi ise maço erkek karakterin karşısında yer alan, melankolik bakışa sahip erkektir (Lemish ve Lahav, 2004: 149). Bu reklamdaki erkek karakterin bakışının melankolik olduğu görülmektedir. Melankolik erkek aynı zamanda cinsel bir arzu da barındırmaktadır.

\section{Sonuç}

Reklamı sadece kullanım değerinin değişim değerine karşı olması bakımından incelemek yeterli değildir. Ürünlerin, artık bizler için ne yapabildikleri üzerinden değil onları satın alarak kendimizi nasıl temsil ve ifade ettiğimiz üzerinden tanıtılmaları gerekmektedir (Tinic, 1997: 14). Reklamlar aynı zamanda birer anlamlar, imgeler, simgeler depolarıdır. Her ne kadar reklamın öncelikli amacı satış ve bilgilendirme olsa da reklam aynı zamanda yoğun bir anlam dünyası içermektedir. $\mathrm{Bu}$ çalışmada, reklamın anlam dünyasında yer alan ve reklamlar aracıllğıyla üretilen/yeniden üretilen erkekliğin temsil biçimleri diğer bir ifade ile reklamlarda nasıl kurulduğu değerlendirilmeye çalışılmış, reklamlardaki görsellik ve söylemi çeşitli çalışmalardan yola çıkarak incelemenin daha uygun olacağ düşünülmüştür. İncelenen altı reklamda hakim erkeklik biçimleri "trendi, androjen, erotik, tüketici, şehvetli erkek" olmak üzere çeşitli biçimlerde inşa edilmiştir. Kurulan erkeklik biçimleri değerlendirilirken bakış, dokunma ve duruş gibi görsel unsurlar da değerlendirilmiştir. İncelenen reklamlarda genel olarak alıcıya/okuyucuya yönelik soğuk ve mesafeli bir bakış vardır. Bu bakışın nedenlerinden ilki, erkeklik biçimlerinin kendisini soğuk bir bakış üzerinden ifade etmesi; ikincisi ise reklamların yayınlandığı dergilerin okuyucularının daha çok üst sosyo-ekonomik sınıfa mensup oldukları varsayımından kaynaklı reklamı yapılan markaların "özel bir tüketici grubuna yönelik olduğu” anlayışının mesafe üzerinden kurulması olduğu öne sürülebilir. Öyle ki Stibbe (2004: 34) Men’s Health dergisinin okuyucularının yüksek eğitimli, üst sosyo-ekonomik sınıfa mensup ve erkek tahakkümünü yeniden üreten erkeklerden oluştuğunu dile getirmektedir. Altı reklamın ikisinde yer alan kısa metinler de söylemsel olarak analiz edilmeye çalışılmıştır. Söylemlerin biri, erkeklikten yola çıkarak toplumsal yapıyı düzenleyici bir şekilde kurulmuşken diğeri ise yine erkeklikten hareketle otoriteryen bir dilin kullanımı üzerinden kurulmuştur.

Reklamlarda inşa edilen ve sunulan erkekliğin toplumdaki ekonomik, toplumsal ve kültürel kodlardan bağımsız olmadığı özellikle hem erkek hem kadın karakterlerin yer aldığı reklamlarda erkeğin daha bir merkezi konumda bulunduğu 
Kılınç, Ö. / Journal of Yasar University, 2015 10(37) 6402- 6412

söylenebilir. Dolayısıyla sadece satışa yönelik bir iletişim biçimi olmayan reklamı, söylemin yer aldığı, kurulduğu ve anlam yarattığı bir alan olarak görmek reklama yönelik eleştirel bir okuma yapmayı mümkün kılabilir.

\section{KAYNAKÇA}

Alexander, S. M. (2003). Stylish Hard Bodies: Branded Masculinity in Men’s Health Magazine. Sociological Perspectives, 46 (4), 535-554.

An, D. ve Kim, S. (2007). Relating Hofstede’s Masculinity Dimension to Gender Role Portrayals in Advertising: A CrossCultural Comparison of Web Advertisements. International Marketing Review, 24 (2), 181-207.

Bassett, M. (2009). Masculinity in Magazine Advertisements: Is it in the Eye of the Beholder? Unpublished Master's Thesis, The University of Alabama, Tuscaloosa, USA.

Baudrillard, J. (2013). Tüketim Toplumu: Söylenceleri-Yapıları (Çev: Hazal Deliçaylı ve Ferda Keskin). İstanbul: Ayrıntı Yayınları.

Berger, J. (2014). Görme Biçimleri (Çev: Yurdanur Salman). İstanbul: Metis Yayınları.

Bordo, S. (2000). The Male Body: A New Look at Men in Public and in Private. New York: Farrar, Straus and Giroux.

Canpolat, N. (2005). Bilginin Arkeoloğu Michel Foucault. Kadife Karanlık (Haz: N. Rigel vd.). İstanbul: Su Yayınevi, 75130.

Chan, S. H. Ve Leung, L. C. (2005). Between Viewing and Consuming: How Aging Women in Hong Kong Negotiate Television Advertisements. Feminist Media Studies, 5 (2), 123-140.

Coltrane, S. ve Adams, M. (1997). Work-Family Imagery and Gender Stereotypes: Television and the Reproduction of Difference. Journal of Vocational Behavior 50, 323-347.

Connell, R. W. (1998). Toplumsal Cinsiyet ve İktidar: Toplum, Kişi ve Cinsel Politika (Çev: Cem Soydemir). İstanbul: Ayrintı Yayınları.

Connell, R. W. ve Messerschmidt, J. W. (2005). Hegemonic Masculinity Rethinking the Concept. Gender \& Society, 19 (6), 829-859.

Crane, D. (2003). Moda ve Gündemleri: Giyimde Sınıf, Cinsiyet ve Kimlik (Çev: Özge Çelik). İstanbul: Ayrıntı Yayınları.

Çoban, B. (2005). Aynalar Şövalyesi ya da Bilinçdışının Kaşifi Lacan. Kadife Karanlık (Haz: N. Rigel vd.). İstanbul: Su Yayınevi, 277-291.

Fairclough, N. L. (1992). Discourse and Social Change. Cambridge, MA: Polity Press.

Fairclough, N. L. ve Wodak, R. (1997). Critical Discourse Analysis. Discourse Studies. A Multidisciplinary Introduction, Vol. 2. Discourse as Social Interaction (Ed: T. A. van Dijk). London: Sage 258-284.

Featherstone, M. (2013). Postmodernizm ve Tüketim Kültürü (Çev: Mehmet Küçük). İstanbul: Ayrıntı Yayınları.

Goldman, R. (1992). Reading Ads Socially. Norfolk, UK: Biddles Ltd.

Hall, S. (Ed.). (1997). Representation: Cultural Representations and Signifying Practices. London: Sage.

Harrison, C. (2008). Real Men Do Wear Mascara: Advertising Discourse and Masculine Identity. Critical Discourse Studies, 5 (1), 55-74.

Katz, J. (2003). Advertising and the Construction of Violent White Masculinity: From Eminem to Clinque for Men. Gender, Race, and Class in Media (Ed: Gail Dines ve Jean M. Humez). Sage, 349-358.

Khoo, M. ve Karan, K. (2007). Macho or Metrosexual: The Branding of Masculinity in FHM Magazine in Singapore. Intercultural Communication Studies, 16 (1), 34-45.

Lemish, D. ve Lahav, I. (2004). Much Ado About Nothing? Masculinities in Israeli Advertising. Feminist Media Studies, 4 (2), 147-163.

Lull, J. (2001). Medya, İletişim, Kültür (Çev: Nazife Güngör). Ankara: Vadi Yayınları.

Plumwood, V. (2004). Feminizm ve Doğaya Hükmetmek (Çev: Başak Ertür). İstanbul: Metis Yayınları.

Pritchard, A. (2001). Tourism and Representation: A Scale for Measuring Gendered Portrayals. Leisure Studies, 20 (2), 7994.

Purvis, T. ve Hunt, A. (2014). Söylem, İdeoloji, Söylem, İdeoloji, Söylem, İdeoloji. . . (Çev: Simten Coşar). Moment Dergi, 2014, 1 (1): 9-36.

Ricciardelli, R., Clow, K. A. ve White, P. (2010). Investigating Hegemonic Masculinity: Portrayals of Masculinity in Men’s Lifestyle Magazines. Sex Roles, 63, 64-78.

Rohlinger, D. A. (2002). Eroticizing Men: Cultural Influences on Advertising and Male Objectification. Sex Roles, 46 (3-4), 61-74.

Schroeder, J. E. ve Zwick, D. (2004). Mirrors of Masculinity: Representation and Identity in Advertising Images. Consumption, Markets \& Culture, 7 (1), 21-52.

Shaw, P. ve Tan, Y. (2014). Race and Masculinity: A Comparison of Asian and Western Models in Men's Lifestyle Magazine Advertisements. Journalism \& Mass Communication Quarterly, 91(1) 118-138.

Slevin, K. F. ve Linneman, T. J. (2009). Old Gay Men’s Bodies and Masculinities. Men and Masculinities, 1-25. 
Kılınç, Ö. / Journal of Yasar University, 2015 10(37) 6402- 6412

Stibbe, A. (2004). Health and the Social Construction of Masculinity in Men's Health Magazine. Men and Masculinities, 7, $31-51$.

Tinic, S.A. (1997). United Colors and Untied Meanings: Benetton and the Commodification of Social Issues. Journal of Communication, 47 (3), 3-25.

Trujillo, N. (1991). Hegemonic Masculinity on the Mound: Media Representations of Nolan Ryan and American Sports Culture. Critical Studies in Media Communication, 8 (3), 290-308.

Tuncay, L. Y. (2005). How Male Consumers Construct and Negotiate Their Identities in the Marketplace: Three Essays. Unpublished Doctoral Dissertation, University of Illinois, Urbana-Champaign, USA.

van Dijk, T. A. (2003). Critical Discourse Analysis. The Handbook of Discourse Analysis (Ed: D. Schiffrin, D. Tannen ve H. E. Hamilton). Blackwell Publishing, 352-371.

Wang, J. (2014). Criticising Images: Critical Discourse Analysis of Visual Semiosis in Picture News. Critical Arts, 28 (2), 264-286.

Williamson, J. (2001). Reklamların Dili: Reklamlarda Anlam ve İdeoloji (Çev: Ahmet Fethi). Ankara: Ütopya Yayınevi. GQ Ekim 2014.

Men's Health Kasım 2014. 